\title{
JPEB
}

Jurnal Penelitian Ekonomi dan Bisnis, 4 (1), 2019, Hal: 23 -37

http://www.jpeb.dinus.ac.id

\section{RETURN DAN LIKUIDITAS SAHAM SEBELUM DAN SESUDAH PEMECAHAN SAHAM}

\author{
Irene Natalia* \\ Jurusan Akuntansi, Fakultas Bisnis dan Ekonomika, Universitas Surabaya \\ Jalan Raya Kali Rungkut, Surabaya, Jawa Timur, Indonesia \\ *Corresponding Author : irenenatalia@staff.ubaya.ac.id
}

Diterima: Desember 2018 ; Direvisi: Januari 2019 ; Dipublikasikan: Maret 2019

\begin{abstract}
This study aims to examine the impact of stock split for returns, abnormal returns, and stock liquidity before and after stock split. The research period used is 2016-2018. The number of samples is 37 companies from various types of industries listed on the Indonesia Stock Exchange. The normality has tested by One Sample Kolmogorov Smirnov's Test. All data has normally distributed. Hypothesis testing has done by the Paired Samples Test. The results of hypothesis testing showed (1) no differences before and after stock split for stock return variable and abnormal stock returns variable, and (2) difference before and after stock split for stock liquidity variable.
\end{abstract}

Keywords: Stock Split; Return; Abnormal Return; Stock Liquidity

\begin{abstract}
ABSTRAK
Penelitian ini bertujuan untuk mengkaji dampak pemecahan saham dalam hal return, return tak normal, dan likuiditas saham sebelum dan sesudah pemecahan saham. Periode penelitian yang digunakan adalah 2016-2018. Jumlah sampel sebanyak 37 perusahaan dari berbagai jenis industri yang terdaftar di Bursa Efek Indonesia. Normalitas diuji dengan uji One Sample Kolmogorov Smirnov. Semua data telah terdistribusi normal. Pengujian hipotesis dilakukan dengan uji beda berpasangan. Hasil pengujian hipotesis menunjukkan (1) tidak ada perbedaan sebelum dan sesudah pemecahan saham untuk variabel return saham dan return taknormal saham, dan (2) ada perbedaan sebelum dan sesudah pemecahan saham untuk likuiditas saham.
\end{abstract}

Kata Kunci: Pemecahan Saham; Return; Return Taknormal; Likuiditas Saham 


\section{PENDAHULUAN}

Perkembangan pasar saham suatu negara selalu menarik untuk diteliti. Pasar modal merupakan sarana perusahaan mendapatkan investasi modal dan sarana investor menginvestasikan dana. Hal ini menyebabkan aktivitas perdagangan saham dan kesejahteraan investor menjadi perhatian utama.

Beberapa aktivitas yang berpengaruh pada jumlah saham biasa yang beredar antara lain pemecahan saham (stock split), penggabungan saham (reverse stock split), pembagian dividen saham (stock devidend), pembelian kembali saham tresuri, dan sebagainya. Salah satu aktivitas yang banyak dilakukan oleh perusahaan adalah pemecahan saham.

Pemecahan saham adalah aktivitas membagi atau memecah saham menjadi nilai nominal lebih kecil dengan rasio tertentu dan diikuti penambahan jumlah saham yang beredar sesuai dengan dengan rasio tertentu. Pemecahan saham meningkatkan jumlah lembar saham yang beredar. Aktivitas pemecahan saham bukan merupakan aktivitas kapitalisasi (noncapitalizing event) karena tidak ada perubahan nilai nominal total modal saham biasa dan premium saham sebelum dan sesudah pemecahan saham. Meskipun tidak ada perubahan nilai buku saham, pemecahan saham banyak dilakukan dan menunjukkan kecenderungan peningkatan dari tahun ke tahun (Gambar 1). Beberapa perusahaan melakukan pemecahan saham sebanyak dua kali dalam kurun waktu enam tahun, misalnya PT Arwana Citramulia Tbk (10 September 2009 dan 05 Juli 2013) dan PT Sarana Menara Nusantara Tbk (19 Juli 2013 dan 27 Juni 2018). Harga saham cenderung meningkat setelah pemecahan saham (Hu et al., 2017). Hal ini menyebabkan perlunya pengujian lebih lanjut.

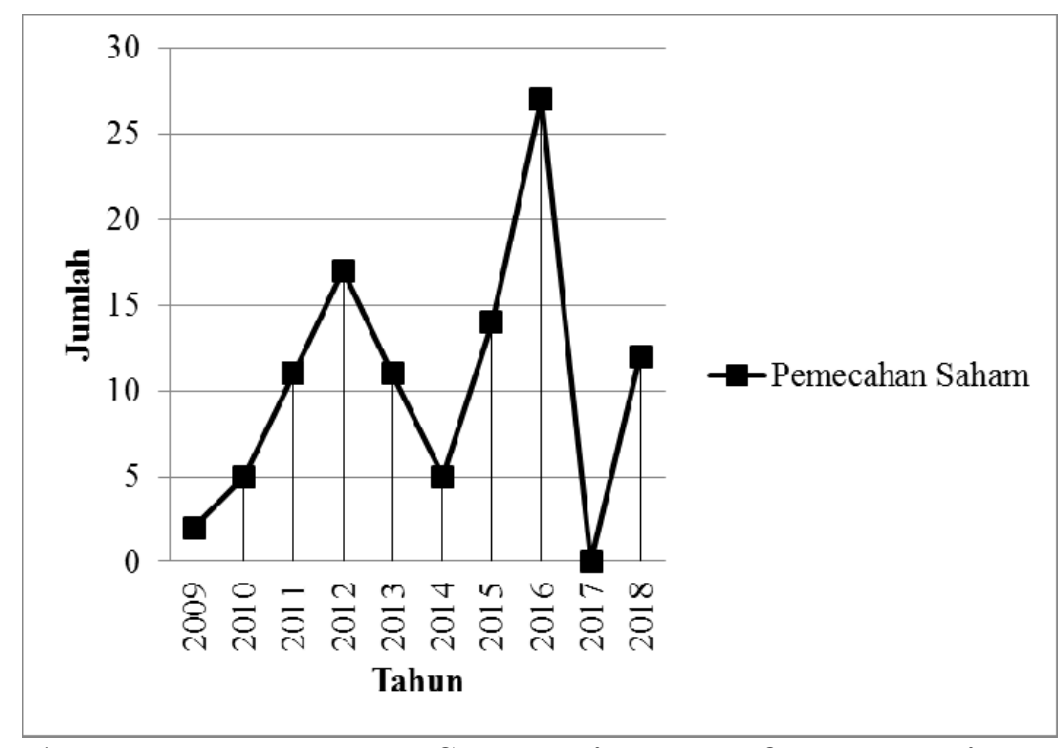

\section{Gambar 1. Jumlah Pemecahan Saham di Bursa Efek Indonesia Periode 2009-2018}

Beberapa alasan yang melatarbelakangi perusahaan melakukan pemecahan saham. Alasan kesatu adalah manajemen perusahaan ingin memberikan sinyal informasi positif kepada investor tentang probabilitas masa depan perusahaan, misalnya keyakinan pertumbuhan laba perusahaan di masa depan (Ikenberry dan Ramnath, 2002; Ikenberry, Rankine, and Stice, 1996; dan Klein dan Peterson, 1989 dalam Hu et al., 2017). Informasi akuntansi menjadi sangat penting bagi investor untuk mengurangi kesenjangan informasi yang dimiliki investor (prinsipal) dibanding manajemen (agen). Sinyal informasi dari manajemen menjadi perhatian bagi investor, karena memiliki dampak pada peningkatan nilai pasar perusahaan dan return yang diterima pemegang saham pada saat pengumuman dan eksekusi pemecahan saham. Alasan kedua, pemecahan saham terjadi saat manajemen ingin meraih rentang perdagangan optimal (optimal trading range) dalam harga untuk 
memperbesar kelaikan pasar (Fernando, Krishnamurthy, dan Spindt, 1999; dan Huang and Weingartner, 2000 dalam $\mathrm{Hu}$ et al., 2017). Manajemen akan melakukan pemecahan saham saat harga pasar saham dianggap tinggi atau mahal, agar likuiditas saham meningkat. Harga saham dan nilai nominal saham akan menurun setelah pemecahan saham, sedangkan jumlah lembar saham akan meningkat secara proporsional.

Likuiditas saham menunjukkan seberapa banyak frekuensi perdagangan saham. Likuiditas saham yang tinggi dapat menarik minat investor terhadap saham perusahaan untuk mendapatkan return jangka pendek maupun return jangka panjang. Investor akan meningkatkan volume (jumlah) lot saham yang dibeli dan meningkatkan kelaikan pasar.

Relevansi aktivitas pemecahan saham bagi investor adalah kemampuan aktivitas pemecahan saham untuk memberikan perbedaan bagi investor, terutama yang berkaitan dengan return. Manajemen berupaya meningkatkan likuiditas saham dari peningkatan volume perdagangan dan investor berupaya mendapatkan capital gain (return) dari perubahan harga saham. Penelitian mengenai relevansi aktivitas pemecahan bagi investor menjadi penting karena terdapat argumentasi bahwa pemecahan saham juga dapat dianggap sebagai tindakan kosmetik yang tidak meningkatkan nilai perusahaan yang tidak menguntungkan bagi investor.

Di Indonesia, aktivitas pemecahan saham terbaru diteliti oleh Hanafie dan Diyani (2016) dan Rahayu dan Murti (2017). Hanafie dan Diyani (2016), dan Rahayu dan Murti (2017) tidak berhasil membuktikan ada perbedaan yang signifikan pada return perusahaan sebelum dan setelah pemecahan saham. Hanafie dan Diyani (2016) berhasil membuktikan ada perbedaan yang signifikan pada return taknormal perusahaan sebelum dan setelah pemecahan saham. Sementara itu, Hanafie dan Diyani (2016), dan Rahayu dan Murti (2017) berhasil membuktikan ada perbedaan yang signifikan pada likuiditas saham (trading volume activity) sebelum dan setelah pemecahan saham. Topik pemecahan saham berkaitan dengan kesejahteraan investor, sehingga topik ini menarik untuk diteliti. Penelitian ini merupakan mereplikasi penelitian terdahulu dengan pembaruan data.

Penelitian ini mengkaji dampak fenomena pemecahan saham dalam hal perbedaan return, return tak normal, dan likuiditas saham sebelum dan sesudah pemecahan saham. Penelitian ini bertujuan untuk mengetahui perbedaan kondisi sebelum dan setelah pemecahan saham. Penelitian ini bermanfaat menjadi bahan masukan bagi manajemen perusahaan sebagai dasar penentuan keputusan pemecahan saham dan investor sebagai dasar keputusan investasi saham.

\section{TINJAUAN PUSTAKA}

\section{Teori Pemberian Sinyal}

Pemecahan saham dilatarbelakangi teori pemberian sinyal (signalling theory). Adanya pihak prinsipal (pemegang saham) dan agen (manajemen) dalam perusahaan, yang mana agen merupakan pihak yang tahu lebih banyak. Perusahaan yang melakukan pemecahan saham ingin memberikan sinyal tentang prospek perusahaan yang baik di masa mendatang. Selain itu, pemecahan saham dilakukan pada saat harga saham terlalu tinggi, agar harga saham lebih rendah dan saham lebih aktif diperdagangkan.

\section{Pemecahan Saham}

Pemecahan saham adalah aktivitas membagi atau memecah saham menjadi nilai nominal lebih kecil dengan rasio tertentu dan diikuti penambahan jumlah saham yang beredar sesuai dengan dengan rasio tertentu. Pemecahan saham menurunkan nilai pari (nilai nominal atau stated value) saham, namun tidak meningkatkan total nilai saham (ekuitas) secara keseluruhan. Tidak ada pencatatan akuntansi yang diperlukan. Tujuan utama pemecahan saham adalah menurunkan nilai pasar saham. 
Pemecahan saham dapat dianggap sebagai tindakan menguntungkan bagi manajemen dan investor. Manajemen berupaya melakukan peningkatan likuiditas saham dari peningkatan volume perdagangan dan investor berupaya mendapatkan capital gain (return) dari perubahan harga saham. Sementara itu, pemecahan saham dapat dianggap sebagai tindakan kosmetik yang tidak meningkatkan nilai perusahaan yang tidak menguntungkan bagi investor.

Pemecahan saham telah diteliti oleh peneliti dalam dan luar negeri. Penelitian pemecahan saham oleh peneliti luar negeri antara lain Dolley (1933), Fama, Fisher, Jensen, dan Roll (1969), Beladi, Chao, dan Hu (2016), dan peneliti lain. Penelitian pemecahan saham oleh peneliti dalam negeri antara lain Suryawijaya dan Setiawan (2002), Hanafie dan Diyani (2016), Rahayu dan Murti (2017), dan peneliti lain. Ketidakkonsistenan hasil penelitian masih terjadi.

\section{Return Saham}

Return saham merupakan hasil yang diperoleh dari investasi (Jogiyanto, 2010:63). Reaksi pasar tampak dalam harga saham umumnya meningkat setelah pengumuman di pasar, namun nilai buku total saham masih tetap (Beladi, Chao, dan $\mathrm{Hu}, 2016$ ). Peningkatan harga pasar saham akan menghasilkan return bagi investor. Pemecahan saham memberikan sinyal tentang probabalitas masa depan perusahaan, misalnya prospek pertumbuhan perusahaan di masa depan. Hal ini menjadi pertimbangan investor mulai membeli saham perusahaan tersebut untuk mengantisipasi return di masa datang. Pembelian dalam jumlah relatif besar akan menyebabkan perubahan harga pasar. Perubahan harga pasar saham akan menyebabkan adanya perbedaan return sebelum dan sesudah pemecahan saham.

Pemecahan saham biasanya didahului oleh suatu periode yang mana tingkat return perusahaan tidak biasa tinggi dan terjadi sebelum pengumuman pemecahan saham mencapai pasar (Fama et al., 1969). Dalam periode tersebut, return perusahaan mengalami kenaikan yang banyak, meliputi kenaikan harga saham, return ekspektasian dan dividen. Hasil pengujian yang dilakukan oleh Fama et al. (1969) menemukan bahwa tingkat return tertinggi terjadi beberapa bulan sebelum pemecahan saham terjadi, sebab pemecahan saham menjadi daya dorong untuk peningkatan return. Sementara itu, ketidakpastian masih akan terjadi pada bulan pemecahan saham. Penyesuaian harga saham yang cepat dengan perkembangan yang terjadi akan menyebabkan adanya perbedaan return saham sebelum dan sesudah peristiwa.

$\mathrm{H}_{1}$ : Terdapat perbedaan pada return saham sebelum dan sesudah pemecahan saham.

\section{Return Taknormal Saham}

Return taknormal (abnormal return) adalah selisih antara return dengan return ekspektasian. Sinyal prospek pertumbuhan perusahaan di masa depan diantisipasi investor dengan mulai membeli saham perusahaan tersebut, sehingga menyebabkan terjadi return di atas rata-rata. Return taknormal dapat disebut sebagai return kelebihan (excess return) merupakan kelebihan dari return yang sesungguhnya terjadi terhadap return normal (Jogiyanto, 2010:94). Return normal merupakan return ekspektasian (return yang diharapkan dari investor). Return sesungguhnya merupakan return yang terjadi pada waktu ke-t yang merupakan selisih harga sekarang relatif terhadap harga sebelumnya (Jogiyanto, 2010:94).

Return taknormal dapat terjadi pada pasar yang bentuk efisiennya setengah kuat. Return taknormal terjadi di seputar pengumuman (publikasi) suatu peristiwa sebagai representasi dari respon pasar (Tandelilin, 2010:105 dalam Hanafie dan Diyanti, 2016). Studi peristiwa untuk pemecahan saham dilakukan oleh Dolley (1933). Dolley (1993) dalam Jogiyanto (2010:6) membuktikan bahwa sebagian besar harga saham bereaksi positif karena peristiwa pemecahan saham ini.

Reaksi pasar terhadap pengumuman pemecahan saham adalah return taknormal positif dalam jangka pendek untuk periode enam hari setelah hari peristiwa (Lamoureux and 
Poon, 1987 dalam Beladi, Chao, dan Hu 2016). Selain itu, Tawatnuntachai and D'Mello (2002) dalam Beladi, Chao, dan $\mathrm{Hu}$ (2016) menemukan reaksi pasar jangka pendek terhadap pemecahan saham dalam bentuk return positif secara signifikan untuk periode peristiwa lima hari $(-2,+2)$ dari tanggal peristiwa. Beladi, Chao, dan $\mathrm{Hu}(2016)$ menemukan reaksi return jangka pendek setelah tanggal peristiwa terutama pemecahan saham yang dilakukan pada bulan Januari (January Effect). Hanafie dan Diyani (2016) berhasil membuktikan ada perbedaan yang signifikan pada return taknormal perusahaan sebelum dan setelah pemecahan saham di Bursa Efek Indonesia periode 2010-2013. Penyesuaian return yang cepat dengan perkembangan yang terjadi akan menyebabkan adanya perbedaan return taknormal saham sebelum dan sesudah peristiwa.

$\mathrm{H}_{2}$ : Terdapat perbedaan pada return taknormal saham sebelum dan sesudah pemecahan saham.

\section{Likuiditas Saham}

Likuiditas adalah kecepatan dan kemudahan yang mana investor dapat merealisasikan nilai kas dari suatu investasi (Bodie, Kane dan Markus, 2018:20). Likuiditas adalah kemampuan untuk membeli atau menjual suatu aset pada harga wajar dalam waktu singkat (Bodie, Kane dan Markus, 2018:58). Sementara itu, pengertian likuiditas yang lain adalah kemampuan untuk memperdagangkan kuantitas dalam jumlah besar, dengan biaya transaksi minimal dan dampak sedikit perubahan harga (Chan, Hameed, dan Kang, 2013). Likuiditas saham adalah kemampuan saham untuk diperdagangkan dengan cepat, mudah dan dalam jumlah banyak dengan waktu yang singkat.

Pertimbangan perusahaan yang melakukan pemecahan saham adalah ingin meningkatkan volatilitas saham agar dapat mempertahankan tingkat likuiditas saham perusahaan, bahkan meningkatkannya. Peningkatan involatilitas dalam aktivitas perdagangan saham akan menyebabkan penurunan likuiditas saham (Chan, Hameed, dan Kang, 2013). Harga saham yang lebih rendah dibandingkan sebelum pemecahan saham menjadi faktor yang menarik minat investor untuk lebih memperdagangkan saham perusahaan dengan volume (jumlah lembar) saham relatif lebih banyak, sehingga mempengaruhi tingkat likuiditas saham tersebut.

Copeland (1979) menginvestigasi dampak likuiditas saham dengan menggunakan ukuran volume perdagangan dan persentase perubahan biaya. Copeland (1979) membuktikan likuiditas saham yang lebih rendah setelah pemecahan saham. Copeland (1979) menyimpulkan bahwa likuiditas relatif menunjukkan hasil penurunan permanen mengikuti pemecahan saham. Menurut Suryawijaya dan Setiawan (2002), pertimbangan investor untuk melakukan transaksi setelah tanggal peristiwa adalah untuk mengamankan investasi yang dimiliki. Suryawijaya dan Setiawan (2002), Hanafie dan Diyani (2016), dan Rahayu dan Murti (2017) berhasil membuktikan ada perbedaan likuiditas saham (trading volume activity) yang signifikan sebelum dan setelah pemecahan saham.

H3: Ada perbedaan likuiditas saham sebelum dan sesudah pemecahan saham.

\section{METODE PENELITIAN}

\section{Sampel dan Data}

Populasi yang digunakan adalah perusahaan manufaktur yang terdaftar pada Bursa Efek Indonesia dari tahun 2016 sampai dengan 2018. Teknik pengambilan sampel dalam penelitian ini adalah dengan menggunakan purposive sampling. Beberapa kriteria yang ditetapkan untuk memperoleh sampel adalah sebagai berikut: (1) Perusahaan yang telah terdaftar pada BEI selama periode pengamatan, (2) perusahaan melakukan pemecahan saham antara tahun 2016-2018, dan (3) tidak terjadi peristiwa pengganggu selama periode peristiwa, seperti perusahaan tidak melakukan pengumuman dividen. Periode penelitian yang 
digunakan selama 3 tahun, yaitu 2016 sampai 2018. Perusahaan yang melakukan pemecahan saham selama tahun 2016 sebanyak 25 perusahaan, tahun 2017 tidak ada, dan tahun 2018 sebanyak 12 perusahaan.

Adanya reaksi untuk aktivitas pemecahan saham dapat diamati dalam bentuk perubahan harga pasar dan likuiditas saham pada periode sebelum dan sesudah dilakukan stock split. Periode waktu yang digunakan ada dua jenis, yaitu periode estimasi dan periode peristiwa (periode jendela). Periode estimasi yang digunakan selama 200 hari bursa sebelum dimulainya periode peristiwa. Periode peristiwa (periode jendela) yang digunakan adalah 5 hari bursa sebelum tanggal $t_{0}$ dan 5 hari bursa setelah tanggal $t_{0}$.

$\mathrm{t}_{0}$ berdasar pada cum date. Cum date adalah tanggal akhir (Cum) perdagangan saham dengan nilai nominal lama di seluruh pasar (Bursa Efek Indonesia). Cum date dipilih karena tanggal ini merupakan tanggal terakhir investor masih dapat memilih mempertahankan saham yang ada, membeli saham tambahan, atau menjual saham yang dimiliki, sehingga reaksi keputusan investor untuk mengantisipasi sinyal dapat diukur.

Data yang digunakan dalam penelitian ini adalah data sekunder, yaitu data aktivitas pemecahan saham perusahaan dari basis data Kustodian Sentral Efek Indonesia (KSEI), data indeks Bursa Efek Indonesia (BEI), data harga saham penutupan dan volume perdagangan objek penelitian yang diperoleh dari basis data yahoo finance (www.finance.yahoo.com) dan yang tersedia secara daring. Data aktivitas perusahaan yang dikumpulkan adalah tanggal peristiwa pemecahan saham menggunakan tanggal yang diumumkan di situs web KSEI (http://www.ksei.co.id). Data indeks harga saham BEI dan harga saham penutupan objek penelitian dikumpulkan selama periode estimasi sampai dengan periode peristiwa, yaitu 205 hari sebelum dan 5 hari setelah tanggal pengumuman pemecahan saham. Data volume perdagangan dikumpulkan selama periode estimasi sampai periode peristiwa, yaitu 5 hari sebelum dan 5 hari setelah tanggal pengumuman pemecahan saham. Data jumlah saham yang beredar diperoleh dari laporan keuangan auditan tahun 2016-2017.

Perusahaan yang menjadi sampel diperiksa efek pengganggu agar hasil pengujian tidak bias. Efek pengganggu dapat berupa pengumuman dividen selama periode peristiwa. Efek pengganggu dapat diatasi dengan cara membuang sampel perusahaan yang mengalami efek pengganggu. Dari tabel berikut diketahui bahwa tidak ada sampel yang mengalami efek pengganggu. Berdasarkan kriteria yang telah diperoleh sampel dengan rincian sebagai berikut, tabel berikut ini berisi hasil pemilihan sampel.

Jumlah sampel tahun 2016 sampai dengan tahun 2018 sebanyak 37 perusahaan dari berbagai jenis industri. Hasil pengambilan sampel ditunjukkan dalam Tabel 1.

Tabel 1. Hasil Pengambilan Sampel

\begin{tabular}{lc}
\hline \multicolumn{1}{c}{ Kriteria Sampel } & Jumlah \\
\hline Perusahaan sampel tahun 2016 & 25 \\
Perusahaan sampel tahun 2017 & 0 \\
Perusahaan sampel tahun 2018 & 12 \\
\hline Jumlah observasi selama tahun 2016-2018 & 37 \\
Perusahaan tidak melakukan pengumuman dividen (peristiwa & 0 \\
pengganggu) selama periode peristiwa & \\
Data outlier & 0 \\
\hline Jumlah sampel & 37 \\
\hline
\end{tabular}

Sebagian besar sampel bukan berasal dari kelompok saham LQ45. Kelompok saham LQ45 menunjukkan saham dari 45 perusahaan yang memiliki memiliki likuiditas tinggi dan 
kapitalisasi pasar besar serta didukung oleh fundamental perusahaan yang baik dibandingkan semua saham yang tercatat di Bursa Efek Indonesia (Bursa Efek Indonesia, 2019). Daftar nama perusahaan sampel ditunjukkan dalam Tabel 2.

Tabel 2. Daftar Nama Sampel

\begin{tabular}{|c|c|c|c|c|}
\hline No & $\begin{array}{c}\text { Kode } \\
\text { Perdagangan }\end{array}$ & Nama Perusahaan & $\begin{array}{c}\text { Cum Date } \\
\text { Pemecahan } \\
\text { Saham }\end{array}$ & $\begin{array}{c}\text { Kelompok } \\
\text { Saham } \\
\text { LQ45 }\end{array}$ \\
\hline 1 & AIMS & Akbar Indo Makmur Stimec Tbk & 1-Aug-16 & Tidak \\
\hline 2 & ALKA & Alakasa Industrindo Tbk & 18-Mar-16 & Tidak \\
\hline 3 & ASBI & Asuransi Bintang Tbk. & 25-Jul-16 & Tidak \\
\hline 4 & ASMI & Asuransi Kresna Mitra Tbk. & 4-Aug-16 & Tidak \\
\hline 5 & BIMA & Primarindo Asia Infrastructure & 26-Aug-16 & Tidak \\
\hline 6 & BTON & Betonjaya Manunggal Tbk. & 29-Jul-16 & Tidak \\
\hline 7 & CNTX / CNTB & Century Textile Industry Tbk. & 11-Aug-16 & Tidak \\
\hline 8 & ERTX & Eratex Djaja Tbk. & 28-Jun-16 & Tidak \\
\hline 9 & HMSP & H.M. Sampoerna Tbk. & 13-Jun-16 & $\mathrm{Ya}$ \\
\hline 10 & ICBP & Indofood CBP Sukses Makmur Tbk & 26-Jul-16 & $\mathrm{Ya}$ \\
\hline 11 & IKBI & Sumi Indo Kabel Tbk. & 20-Sep-16 & Tidak \\
\hline 12 & IMPC & Impack Pratama Industri Tbk. & 21-Jun-16 & Tidak \\
\hline 13 & ITMA & Sumber Energi Andalan Tbk. & 9-Sep-16 & Tidak \\
\hline 14 & KICI & Kedaung Indah Can Tbk & 22-Aug-16 & Tidak \\
\hline 15 & KONI & Perdana Bangun Pusaka Tbk & 19-Feb-16 & Tidak \\
\hline 16 & KREN & Kresna Graha Investama Tbk. & 22-Jun-16 & Tidak \\
\hline 17 & MYOR & Mayora Indah Tbk. & 3-Aug-16 & Tidak \\
\hline 18 & MYRX & Hanson International Tbk. & 12 -Aug-16 & $\mathrm{Ya}$ \\
\hline 19 & PADI & Minna Padi Investama Sekuritas & 13-Jul-16 & Tidak \\
\hline 20 & PSAB & J Resources Asia Pasifik Tbk. & 16-Jun-16 & Tidak \\
\hline 21 & RAJA & Rukun Raharja Tbk. & 6-Jun-16 & Tidak \\
\hline 22 & SMSM & Selamat Sempurna Tbk. & 1-Nov-16 & Tidak \\
\hline 23 & TBMS & Tembaga Mulia Semanan Tbk. & 11-Jul-16 & Tidak \\
\hline 24 & TIRA & Tira Austenite Tbk & 26-Jan-16 & Tidak \\
\hline 25 & TOTO & Surya Toto Indonesia Tbk. & 19-Oct-16 & Tidak \\
\hline 26 & BLTZ & Graha Layar Prima Tbk. & 22-Jun-18 & Tidak \\
\hline 27 & CLEO & Sariguna Primatirta Tbk. & 2-Jul-18 & Tidak \\
\hline 28 & GEMA & Gema Grahasarana Tbk. & 12-Jul-18 & Tidak \\
\hline 29 & IKAI & Intikeramik Alamasri Industri & 12-Jul-18 & Tidak \\
\hline 30 & MAPI & Mitra Adiperkasa Tbk. & 31-May-18 & Tidak \\
\hline 31 & MARI & Mahaka Radio Integra Tbk. & 16-Jul-18 & Tidak \\
\hline 32 & MINA & Sanurhasta Mitra Tbk. & 3-Jul-18 & Tidak \\
\hline 33 & TOPS & Totalindo Eka Persada Tbk. & 6-Jul-18 & Tidak \\
\hline 34 & TOWR & Sarana Menara Nusantara Tbk. & 27-Jun-18 & Tidak \\
\hline 35 & BUVA & Bukit Uluwatu Villa Tbk. & 31-Jul-18 & Tidak \\
\hline 36 & MFIN & Mandala Multifinance Tbk. & 27-Aug-18 & Tidak \\
\hline 37 & KPIG & MNC Land Tbk. & $1-O c t-18$ & Tidak \\
\hline
\end{tabular}

Uji normalitas One Sample Kolmogorov Smirnov dilakukan untuk mengetahui apakah data terdistribusi normal (Ghozali, 2006:30). Data yang terdistribusi normal ditunjukkan dengan nilai signifikansi di atas 5\%. Hasil uji normalitas menunjukkan seluruh 
data telah terdistribusi normal. Jumlah sampel yang digunakan dalam penelitian ini sebanyak 37 observasi selama tahun 2016-2018. Hasil pengujian normalitas ditunjukkan dalam Tabel 3.

Tabel 3. Output pengujian uji normalitas dengan One-Sample Kolmogorov-Smirnov Test

\begin{tabular}{|c|c|c|c|c|c|c|c|}
\hline & & $\begin{array}{l}\text { Rata-rata } \\
\text { Return } \\
\text { Sebelum }\end{array}$ & $\begin{array}{c}\text { Rata-rata } \\
\text { Return } \\
\text { Setelah }\end{array}$ & $\begin{array}{l}\text { Rata-rata } \\
\text { Return } \\
\text { Taknorma } \\
\text { 1 Sebelum }\end{array}$ & $\begin{array}{c}\text { Rata-rata } \\
\text { Return Tak } \\
\text { Normal } \\
\text { Setelah }\end{array}$ & $\begin{array}{c}\text { Rata-rata } \\
\text { Likuiditas } \\
\text { Saham } \\
\text { Sebelum }\end{array}$ & $\begin{array}{c}\text { Rata-rata } \\
\text { Likuiditas } \\
\text { Saham } \\
\text { Setelah }\end{array}$ \\
\hline \multicolumn{2}{|l|}{$\mathrm{N}$} & 5 & $\overline{5}$ & 5 & $\overline{5}$ & $\overline{5}$ & 5 \\
\hline Normal & Mean & .0112527 & 0194744 & .0094652 & .0176869 & .0033990 & .0025862 \\
\hline Parameters $^{\mathrm{a}, \mathrm{b}}$ & Std. Deviation & .01133949 & .02811244 & .01133949 & .02811244 & .00047369 & .00076820 \\
\hline Most Extreme & Absolute & .352 & .277 & .352 & .277 & .237 & .143 \\
\hline Differences & $\begin{array}{l}\text { Positive } \\
\text { Negative }\end{array}$ & $\begin{array}{r}.352 \\
-.197\end{array}$ & $\begin{array}{r}.277 \\
-.230\end{array}$ & $\begin{array}{r}.352 \\
-.197\end{array}$ & $\begin{array}{r}.277 \\
-.230\end{array}$ & $\begin{array}{r}.212 \\
-.237\end{array}$ & $\begin{aligned} .143 \\
-.134\end{aligned}$ \\
\hline \multicolumn{2}{|c|}{ Kolmogorov-Smirnov Z } & .786 & .619 & .786 & .619 & .529 & .319 \\
\hline \multicolumn{2}{|c|}{ Asymp. Sig. (2-tailed) } & .567 & .838 & .567 & .838 & .942 & 1.000 \\
\hline \multicolumn{2}{|c|}{$\begin{array}{l}\text { a. Test distribution is Normal. } \\
\text { b. Calculated from data. }\end{array}$} & & & & & & \\
\hline
\end{tabular}

\section{Variabel dan Pengukuran Variabel}

\section{Return}

Return diukur dengan menggunakan rata-rata return sesungguhnya. Return sesungguhnya adalah selisih harga sekarang relatif terhadap harga sebelumnya.

$$
R_{t, t}=\frac{P_{t, t}-P_{t, t-1}}{P_{t, t-1}}
$$

Keterangan: $\mathrm{R}_{\mathrm{i}, \mathrm{t}}$ adalah return sesungguhnya yang terjadi untuk sekuritas ke-i pada periode peristiwa ke-t; $\mathrm{P}_{\mathrm{i}, \mathrm{t}}$ adalah harga sekarang relatif untuk sekuritas ke-i pada periode peristiwa ke-t; $\mathrm{P}_{\mathrm{i}, \mathrm{t}-1}$ adalah harga sekarang relatif untuk sekuritas ke-i pada periode peristiwa ke-t-1 (perioda lalu); $i$ adalah perusahaan ke-i; $t$ adalah hari ke-t.

Tahapan berikutnya adalah penghitungan rata-rata return harian selama periode peristiwa. Nilai ini akan digunakan dalam uji beda.

$$
R R_{t}=\frac{\sum_{i=19}=-R_{t}}{2 x}
$$

Keterangan: $\mathrm{RR}_{\mathrm{t}}$ adalah rata-rata return sesungguhnya yang terjadi secara harian untuk seluruh sekuritas sampel pada periode peristiwa ke-t (lima hari sebelum dan lima hari sesudah $\left.\mathrm{t}_{0}\right) ; \Sigma \mathrm{R}_{\mathrm{t}}$ adalah penjumlahan return sesungguhnya yang terjadi secara harian untuk seluruh sekuritas sampel pada periode peristiwa ke-t (lima hari sebelum dan lima hari sesudah $\left.\mathrm{t}_{0}\right) ; \Sigma i$ adalah jumlah sampel perusahaan; $t$ adalah hari ke- $t$.

\section{Return Taknormal}

Return taknormal (abnormal return) adalah selisih antara return sesungguhnya yang terjadi dengan return ekspektasian.

$$
R T N_{i t}=R_{k, t}-E\left(R_{i, t}\right)
$$


Keterangan: $\mathrm{RTN}_{\mathrm{i}, \mathrm{t}}$ adalah return tak normal sekuritas ke-i pada periode peristiwa ke-t; $\mathrm{R}_{\mathrm{i}, \mathrm{t}}$ adalah return sesungguhnya yang terjadi untuk sekuritas ke-i pada periode peristiwa ke-t; $\mathrm{E}\left(\mathrm{R}_{\mathrm{i}, \mathrm{t}}\right)$ adalah return ekspektasian sekuritas ke-i pada periode peristiwa ke-t; $i$ adalah perusahaan ke-i; $t$ adalah hari ke-t.

Return ekspektasian dihitung dengan menggunakan model sesuaian rerata. Model sesuaian rerata dipilih karena menunjukkan kesederhanaan dan memiliki kekuatan yang sama dengan model yang disesuaikan dengan risiko (Brown dan Warner, 1980 dalam Jogiyanto: 2010:91)

$$
E\left(R_{t, 2}\right)=\frac{\sum_{i=-6}^{-208} R_{t-i}}{T}
$$

Keterangan: $\mathrm{E}\left(\mathrm{R}_{\mathrm{i}, \mathrm{t}}\right)$ adalah return ekspektasian sekuritas ke-i pada periode peristiwa ke-t; $R_{i, j}$ adalah return realisasian sekuritas ke-i pada periode estimasi ke-j; T adalah lamanya periode estimasi, yaitu 200 hari.

Tahapan berikutnya adalah penghitungan rata-rata return tak normal harian selama periode peristiwa. Nilai ini akan digunakan dalam uji beda.

$$
R R T N_{t}=\frac{\sum_{t=+B}^{t=-5} R T N_{t}}{\Sigma t}
$$

Keterangan: $\mathrm{RRTN}_{\mathrm{t}}$ adalah rata-rata return taknormal secara harian untuk seluruh sekuritas sampel pada periode peristiwa ke-t (lima hari sebelum dan lima hari sesudah $\mathrm{t}_{0}$ ); $\Sigma \mathrm{RTN}_{\mathrm{t}}$ adalah penjumlahan return taknormal secara harian untuk seluruh sekuritas sampel pada periode peristiwa ke-t (lima hari sebelum dan lima hari sesudah $\mathrm{t}_{0}$ ); $\Sigma i$ adalah jumlah sampel perusahaan; $t$ adalah hari ke-t.

\section{Likuiditas Saham}

Likuiditas saham diproksikan dengan aktivitas volume perdagangan (trading volume activity). Aktivitas volume perdagangan merupakan indikator yang relatif mudah digunakan oleh investor untuk melihat perubahan atau reaksi dari suatu informasi. Likuiditas saham suatu saham diukur dengan membagikan jumlah lembar (volume) perdagangan saham perusahaan secara harian dengan jumlah lembar (volume) saham perusahaan yang beredar pada periode peristiwa. Volume perdagangan dan peredaran saham dihitung dengan menggunakan ukuran yang disetarakan dengan rasio pemecahan saham (melakukan penyesuaian volume setelah pemecahan saham).

$$
E S_{t, t}=\frac{V D_{t, t}}{V E E_{t, t}}
$$

Keterangan: $\mathrm{LS}_{\mathrm{i}, \mathrm{t}}$ adalah likuiditas saham sekuritas ke-i pada periode peristiwa ke-t; $\mathrm{VD}_{\mathrm{i}, \mathrm{t}}$ adalah volume dagang atau volume perdagangan saham sekuritas ke-i pada periode peristiwa ke-t; $\mathrm{VE}_{\mathrm{i}, \mathrm{t}}$ adalah volume edar atau volume saham yang beredar dari sekuritas ke-i pada periode peristiwa ke-t.

Tahapan berikutnya adalah penghitungan likuiditas harian selama periode peristiwa. Nilai ini akan digunakan dalam uji beda.

$$
B L S_{\tau}=\frac{\sum_{z}=-\varepsilon_{E}}{\Sigma} L S_{t}
$$


Keterangan: $\mathrm{RLS}_{\mathrm{t}}$ adalah rata-rata likuiditas saham yang terjadi secara harian untuk seluruh sekuritas sampel pada periode peristiwa ke-t (lima hari sebelum dan lima hari sesudah $\left.\mathrm{t}_{0}\right) ; \Sigma L \mathrm{~S}_{\mathrm{t}}$ adalah penjumlahan likuiditas saham secara harian untuk seluruh sekuritas sampel pada periode peristiwa ke-t (lima hari sebelum dan lima hari sesudah $t_{0}$ ); $\Sigma i$ adalah jumlah sampel perusahaan; $t$ adalah hari ke-t.

\section{Teknik Pengujian Hipotesis}

Teknik pengujian hipotesis dilakukan dengan dengan uji beda berpasangan (Paired Sample T-test). Metode pengujian parametrik ini digunakan karena data dari entitas yang saling berhubungan atau ingin melihat perbedaan rata-rata dua sampel yang berhubungan sebelum dan sesudah (Ghozali, 2006:58). Perbandingan kinerja sebelum dan sesudah pemecahan saham dilakukan untuk perusahaan sampel yang sama.

Return, Return taknormal, dan Likuiditas Saham dalam periode jendela diuji signifikansi perbedaan sebelum dan setelah pemecahan saham pada waktu $\mathrm{t}_{0}$. Hipotesis diterima bila tingkat signifikansi (2-tailed) lebih kecil sama dengan sebesar 5\% dengan derajat kebebasan (degree of freedom) n-1. Hipotesis yang diterima berarti data sebelum dan sesudah pemecahan saham menunjukkan perbedaan karena terkena dampak pemecahan saham.

\section{HASIL DAN PEMBAHASAN Statistik Deskriptif}

Berikut ini adalah statistik deskriptif dari data sampel pengujian yang telah memenuhi uji normalitas. Data yang diambil adalah rata-rata harian dari setiap variabel selama lima hari sebelum dan lima hari setelah $\mathrm{t}_{0}$. Deskripsi data tersaji dalam bentuk grafik dalam Gambar 2.

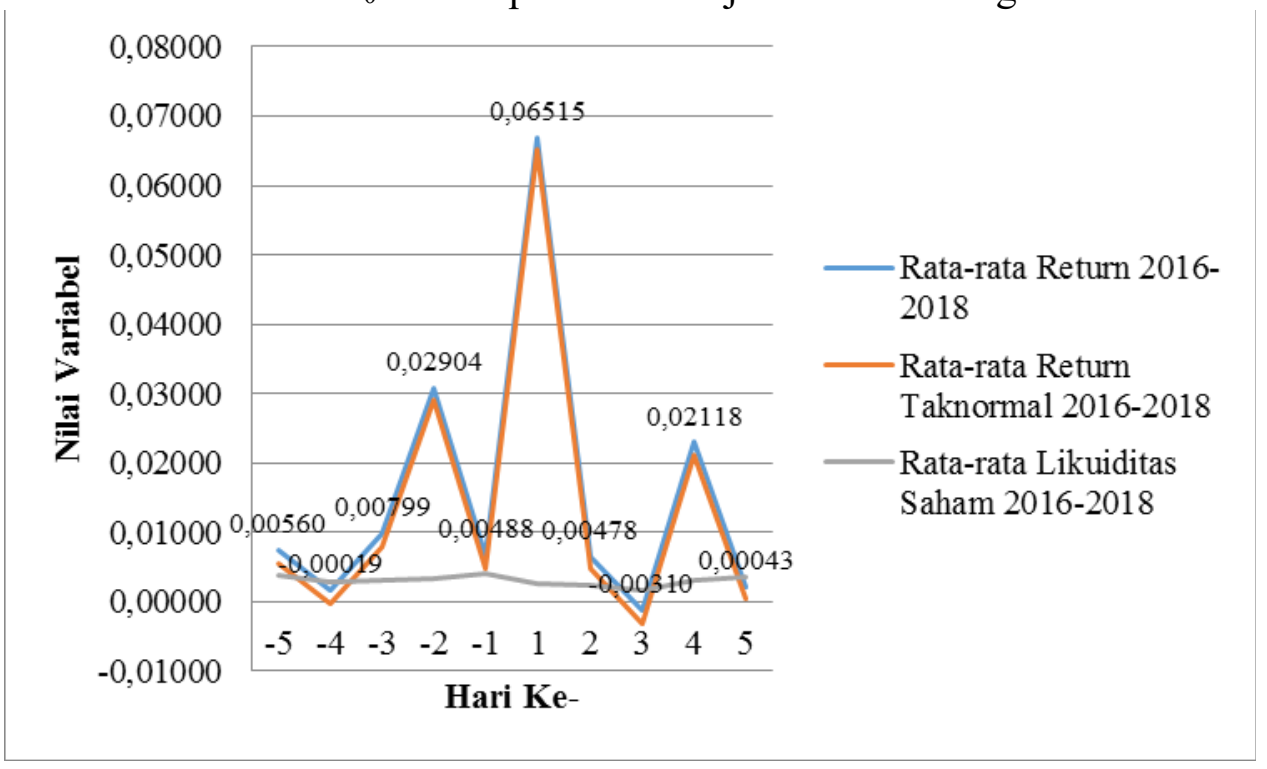

\section{Gambar 2. Deskripsi Data}

Tabel 4 di bawah menunjukkan bahwa variabel return sebelum pemecahan saham memiliki nilai minimum sebesar $-0,00160$, nilai maksimum sebesar 0,03082 , nilai rata-rata sebesar 0,01125, dan standar deviasi sebesar 0,01134. Selain itu, variabel return setelah pemecahan saham memiliki nilai minimum sebesar $-0,00131$, nilai maksimum sebesar 0,06693 , nilai rata-rata sebesar 0,01947 , dan standar deviasi sebesar 0,02811 . Rata-rata return sebelum pemecahan saham sedikit lebih rendah dibanding rata-rata return setelah pemecahan saham. 
Tabel 4. Statistik Deskriptif

\begin{tabular}{|c|c|c|c|c|c|}
\hline Keterangan & $\mathrm{N}$ & Minimum & Maksimum & Rata-rata & $\begin{array}{l}\text { Deviasi } \\
\text { Standar }\end{array}$ \\
\hline RR Sebelum & 5 & ,00160 & 03082 & 01125 &, 01134 \\
\hline RR Setelah & 5 &,- 00131 & ,06693 & 01947 & ,02811 \\
\hline RRTN Sebelum & 5 &,- 00019 & ,02904 & ,00946 & 01134 \\
\hline RRTN Setelah & 5 &,- 00310 & 06515 & 01769 & 02811 \\
\hline RLS Sebelum & 5 & ,00292 & ,00393 & ,00340 & ,00047 \\
\hline RLS Setelah & 5 &, 00156 &, 00358 & ,00259 & ,00077 \\
\hline
\end{tabular}

\section{Keterangan:}

RR Sebelum = Rata-rata Return Sebelum

RR Setelah = Rata-rata Return Setelah

RRTN Sebelum = Rata-rata Return Taknormal Sebelum

RRTN Setelah = Rata-rata Return Taknormal Setelah

RLS Sebelum = Rata-rata Likuiditas Saham Sebelum

RLS Setelah = Rata-rata Likuiditas Saham Setelah

Tabel di atas menunjukkan bahwa variabel return taknormal sebelum pemecahan saham memiliki nilai minimum sebesar $-0,00019$, nilai maksimum 0,02904 , nilai rata-rata sebesar -0,00946, dan standar deviasi sebesar 0,01134. Selain itu, variabel return taknormal setelah pemecahan saham memiliki nilai minimum sebesar $-0,00310$, nilai maksimum 0,06515 , nilai rata-rata sebesar 0,1769 , dan standar deviasi sebesar 0,02811 . Rata-rata return taknormal sebelum pemecahan saham lebih rendah dibanding rata-rata return taknormal setelah pemecahan saham.

Tabel di atas menunjukkan bahwa variabel likuiditas saham sebelum pemecahan saham memiliki nilai minimum sebesar 0,00292 , nilai maksimum 0,00393 , nilai rata-rata sebesar 0,00340, dan standar deviasi sebesar 0,00047. Selain itu, variabel likuiditas saham setelah pemecahan saham memiliki nilai minimum sebesar 0,00156, nilai maksimum 0,00358, nilai rata-rata sebesar 0,00259, dan standar deviasi sebesar 0,00077. Rata-rata likuiditas saham sebelum pemecahan saham lebih rendah dibanding rata-rata likuiditas saham setelah pemecahan saham. 


\section{Hasil Penelitian}

Tabel 5. Ringkasan output SPSS atas pengujian beda antara Return, Return Taknormal dan TVA dengan Paired Samples Test

\begin{tabular}{|c|c|c|c|c|c|c|c|c|c|}
\hline & & \multicolumn{5}{|c|}{ Paired Differences } & \multirow{3}{*}{$\mathrm{t}$} & \multirow{3}{*}{$\mathrm{df}$} & \multirow{3}{*}{$\begin{array}{l}\text { Sig. } \\
(2- \\
\text { tailed })\end{array}$} \\
\hline & & \multirow[t]{2}{*}{ Mean } & \multirow[t]{2}{*}{$\begin{array}{c}\text { Std. } \\
\text { Deviatio } \\
\mathrm{n}\end{array}$} & \multirow[t]{2}{*}{$\begin{array}{l}\text { Std. Error } \\
\text { Mean }\end{array}$} & \multicolumn{2}{|c|}{$\begin{array}{l}95 \% \text { Confidence } \\
\text { Interval of the } \\
\text { Difference }\end{array}$} & & & \\
\hline & & & & & Lower & Upper & & & \\
\hline Pair & Rata-rata Return & -.00822174 & .029312 & .01310875 & -.04461748 & .02817400 & -.627 & 4 & .565 \\
\hline 1 & $\begin{array}{l}\text { Sebelum - Rata- } \\
\text { rata Return } \\
\text { Setelah }\end{array}$ & & 07 & & & & & & \\
\hline $\begin{array}{l}\text { Pair } \\
2\end{array}$ & $\begin{array}{l}\text { Rata-rata Return } \\
\text { Taknormal } \\
\text { Sebelum - Rata- } \\
\text { rata Return Tak } \\
\text { Normal Setelah }\end{array}$ & -.00822174 & $\begin{array}{r}.029312 \\
07\end{array}$ & .01310875 & -.04461748 & .02817400 & -.627 & 4 & .565 \\
\hline $\begin{array}{l}\text { Pair } \\
3\end{array}$ & $\begin{array}{l}\text { Rata-rata } \\
\text { Likuiditas } \\
\text { Saham Sebelum } \\
\text { - Rata-rata } \\
\text { Likuiditas } \\
\text { Saham Setelah }\end{array}$ & .00081277 & $\begin{array}{r}.000569 \\
23\end{array}$ & .00025457 & .00010598 & .00151957 & 3.193 & 4 & .033 \\
\hline
\end{tabular}

Hasil uji hipotesis tersaji pada Tabel 5. Hasil yang diperoleh menunjukkan hanya ada satu hipotesis yang diterima, yaitu likuiditas saham menunjukkan perbedaan sebelum dan sesudah pemecahan saham. Variabel yang lain seperti return saham dan return taknormal saham tidak menunjukkan perbedaan sebelum dan sesudah pemecahan saham.

Hasil uji hipotesis satu diketahui bahwa nilai signifikansi sebesar 0,565 lebih besar dari $0,05(5 \%)$, sehingga hipotesis satu tidak diterima. Hal ini berarti tidak ada perbedaan pada return saham sebelum dan sesudah pemecahan saham.

Hasil uji hipotesis dua diketahui bahwa nilai signifikansi sebesar 0,565 lebih besar dari $0,05(5 \%)$, sehingga hipotesis dua tidak diterima. Hal ini berarti tidak ada perbedaan pada return taknormal saham sebelum dan sesudah pemecahan saham.

Hasil uji hipotesis tiga diketahui bahwa nilai signifikansi sebesar 0,033 lebih kecil dari $0,05(5 \%)$, sehingga hipotesis tiga diterima. Hal ini berarti ada perbedaan pada likuiditas saham sebelum dan sesudah pemecahan saham.

\section{Pembahasan \\ Return}

Tidak ada perbedaan pada return saham sebelum dan sesudah pemecahan saham konsisten dengan hasil seluruh penelitian terdahulu, yaitu Suryawijaya dan Setiawan (2002), Hanafie dan Diyani (2016), dan Rahayu dan Murti (2017). Sinyal informasi tentang prospek pertumbuhan perusahaan di masa datang telah diketahui oleh prinsipal, sehingga asimetri informasi terkait informasi ini tidak terjadi. Hal ini menyebabkan tidak adanya penyesuaian return dalam jumlah besar.

Tingkat return saham perusahaan yang melakukan pemecahan saham hanya mengalami sedikit peningkatan setelah pemecahan saham. Upaya peningkatan return belum berhasil, yang diketahui dari tingkat harga yang stabil. Belum adanya perbedaan return sebelum dan setelah pemecahan saham, hal ini disebabkan beberapa hal.

Penyebab pertama adalah informasi telah terserap oleh pasar dan terefleksi dalam harga pasar saham, yang mana menjadi dasar perhitungan return. Informasi yang terserap 
menyebabkan investor tidak melakukan pembelian dalam jumlah relatif besar yang dapat mempengaruhi harga pasar saham. Tingkat harga yang stabil menyebabkan tidak adanya perbedaan return sebelum dan setelah pemecahan saham. Implikasi informasi dari pemecahan saham terefleksi penuh dalam harga saham paling tidak pada akhir bulan pemecahan saham terjadi (Fama et al., 1969). Sesuai dengan teori pasar saham yang efisien, harga saham akan disesuaikan dengan cepat untuk informasi baru.

Penyebab kedua adalah perusahaan yang melakukan pemecahan saham dengan tanpa didahului peningkatan tingkat return perusahaan yang luar biasa. Investor tidak melihat adanya prospek masa depan perusahaan, seperti peningkatan dividen. Hal ini menyebabkan tingkat harga stabil.

\section{Return Taknormal}

Tidak ada perbedaan pada return taknormal saham sebelum dan sesudah pemecahan saham. Hasil ini tidak konsisten dengan hasil penelitian Hanafie dan Diyani (2016), Ikenberry, Rankine and Stice (1996) dalam Beladi, Chao, dan Hu (2016), Tawatnuntachai and D'Mello (2002) dalam Beladi, Chao, dan Hu (2016), dan Beladi, Chao, dan Hu.

Return taknormal dapat disebut sebagai return kelebihan (excess return) merupakan kelebihan dari return yang sesungguhnya terjadi terhadap return normal. Return normal merupakan return ekspektasian (return yang diharapkan dari investor). Return sesungguhnya merupakan return yang terjadi pada waktu ke-t yang merupakan selisih harga sekarang relatif terhadap harga sebelumnya (Jogiyanto, 2010:94).

Tingkat return taknormal menjadi tidak berbeda sebelum dan sesudah pemecahan saham. Peningkatan nilai return dalam jumlah yang kecil (yang menjadi dasar perhitungan return taknormal), menyebabkan perubahan return taknormal juga dalam nilai yang kecil, sehingga tidak ada perbedaan sebelum dan sesudah pemecahan saham. Hal ini berarti sinyal informasi tentang prospek pertumbuhan perusahaan di masa datang telah terserap oleh pasar dan terefleksi dalam harga pasar saham secara efisien.

\section{Likuiditas Saham}

Ada perbedaan pada likuiditas saham sebelum dan sesudah pemecahan saham. Hasil ini konsisten dengan hasil seluruh penelitian terdahulu, yaitu Hanafie dan Diyani (2016), dan Rahayu dan Murti (2017). Hanafie dan Diyani (2016), dan Rahayu dan Murti (2017) berhasil membuktikan ada perbedaan yang signifikan pada likuiditas saham (trading volume activity) sebelum dan setelah pemecahan saham. Tingkat likuiditas saham menjadi berbeda sebelum dan sesudah pemecahan saham. Hasil ini juga konsisten dengan Copeland (1979).

Copeland (1979) membuktikan likuiditas saham lebih rendah secara permanen setelah pemecahan saham. Hal ini disebabkan jumlah informasi yang lebih banyak sebelum pemecahan saham dibanding setelah pemecahan saham (Copeland, 1969). Jumlah informasi yang diterima lebih rendah menyebabkan volume perdagangan (likuiditas saham) lebih rendah. Pemberian sinyal perusahan telah direspon investor sebelum pemecahan saham. Hal ini menyebabkan respon investor berbeda dengan harapan manajemen perusahaan, yaitu manajemen perusahaan mengharapkan peningkatan likuiditas saham dengan melakukan pemecahan saham. Harga saham yang sudah mencerminkan prospek pertumbuhan perusahaan di masa datang tidak direspon dengan pembelian saham dalam jumlah relatif banyak oleh investor setelah pemecahan saham.

Secara keseluruhan, hasil pengujian ini membuktikan pasar modal Indonesia dalam bentuk efisien setengah kuat. Informasi pemecahan saham telah terserap dalam harga pasar saham. Pemecahan saham menjadi menarik bagi investor yang ingin menjual saham perusahaan yang akan melakukan pemecahan saham karena volume perdagangan saham lebih tinggi sebelum pemecahan saham, sehingga saham menjadi lebih mudah 
diperjualbelikan. Sementara itu, pemecahan saham menjadi tidak menarik bagi investor yang mengharapkan adanya reaksi jangka pendek dalam bentuk return dan return taknormal.

\section{SIMPULAN}

Tidak ada perbedaan pada return saham dan return taknormal saham sebelum dan sesudah pemecahan saham. Hal ini disebabkan sinyal prospek pertumbuhan perusahaan telah diserap oleh pasar dan terefleksi dalam harga pasar saham. Hasil penelitian ketiga adalah ada perbedaan pada likuiditas saham sebelum dan sesudah pemecahan saham. Likuiditas saham lebih rendah setelah pemecahan saham. Investor berespon sesuai dengan teori efisiensi pasar bentuk setengah kuat.

Implikasi hasil penelitian ini adalah bagi manajemen perusahaan dan investor. Setelah mengeluarkan biaya transaksi pemecahan saham, harapan manajemen untuk memberikan perbedaan return dan return taknormal bagi investor, dan peningkatan likuiditas saham tidak terjadi dalam periode peristiwa. Likuiditas saham menurun setelah dilakukan pemecahan saham. Bagi investor baru, pemecahan saham tidak memberikan perbedaan return dan return taknormal, dan peningkatan likuiditas saham tidak terwujud dalam periode peristiwa. Penelitian lebih lanjut mengenai pemecahan saham perlu dilakukan.

\section{DAFTAR PUSTAKA}

Beladi, Hamid, Chi Chur Chao dan May Hu. 2016. Another January effect-Evidence from stock split announcements. International Review of Financial Analysis. 44: 123-138. http://dx.doi.org/10.1016/j.irfa.2016.01.007

Bodie, Zvi, Alex Kane, dan Alan J. Marcus. 2018. Investments (Eleventh Edit). New York: McGraw-Hill Education.

Bursa Efek Indonesia. Indeks Harga Saham. Retrieved February 12, 2019 from https://www.idx.co.id/produk/indeks/

Chan, Kalok, Allaudeen Hameed, dan Wenjin Kang. 2013. Stock Price Synchronicity and Liquidity. Journal of Financial Markets, 16, 414-438. http://dx.doi.org/10.1016/j.finmar.2012.09.007

Copeland, Thomas E. 1979. Liquidity Changes Following Stock Splits. The Journal of Finance. 34(1): 115-141. Retrieved from http://www.jstor.org/stable/2327148

Fama, Eugene F., Lawrence Fisher, Michael C. Jensen, dan Richard Roll. 1969. The Adjustment of Stock Prices to New Information. International Economic Review. 10(1): 1-21. Retrieved from http://links.jstor.org/sici?sici=00206598\%28196902\%2910\%3A1\%3C1\%3ATAOSPT\%3E2.0.CO\%3B2-P

Ghozali, Imam. 2006. Aplikasi Analisis Multivariate Dengan Program SPSS (Cetakan IV). Semarang: Badan Penerbit Universitas Diponegoro.

Hanafie, Lukianto dan Lucia Ari Diyani. 2016. Pengaruh Pengumuman Stock Split Terhadap Return Saham, Abnormal Return dan Trading Volume Activity. Jurnal Bisnis dan Komunikasi, 3(2): 13-20.

Hu, May, Chi-Chur Chao, Chris Malone, dan Martin Young. 2017. Real determinants of stock split announcements. International Review of Economics and Finance. 51: 574598. http://dx.doi.org/10.1016/i.iref.2017.07.027

Jogiyanto. 2010. Studi Peristiwa: Menguji Reaksi Pasar Modal Akibat Suatu Peristiwa. Yogyakarta: Penerbit BPFE.

PT Kustodian Sentral Efek Indonesia. 2018. Retrieved from www.ksei.co.id

Yahoo Finance. 2018. Retrieved from https://finance.yahoo.com/quote/

Rahayu, Dwi, dan Wahyu Murti. 2017. Pengaruh Pemecahan Saham (Stock Split) Terhadap Return Saham, Bid-Ask Spread Dan Trading Volume Activity Pada Perusahaan yang Terdaftar di Bursa Efek Indonesia Periode Tahun 2009 - 2013. Jurnal Akuntansi. 
Irene Natalia : Return Dan Likuiditas Saham Sebelum Dan Sesudah Pemecahan Saham

11(1): 118-134. $\quad$ Retrieved October 13, 2018, from http://ejournal.borobudur.ac.id/index.php/akuntansi/article/view/363/360 